\title{
Peran Ekstrak Kulit Batang Leea angulata Pada Tahap Proliferasi dalam Proses Penyembuhan Luka Kulit Mencit (Mus musculus)
}

\section{Role of Leea angulata Bark Extract on Proliferation Phase of Wound Healing Process in Mouse Skin (Mus musculus)}

\author{
THAUHIDAYATUL HIDAYAH, ANGGRAINI BARLIAN" \\ Sekolah Ilmu dan Teknologi Hayati, Institut Teknologi Bandung, Jl. Ganesha 10. Bandung, Jawa Barat, 40132 \\ Indonesia
}

Diterima 18 September 2021/Disetujui 17 Oktober 2020

\begin{abstract}
Leea angulata is a common plant used by the Sasak people as a medicine to heal the wounds, but the role of $L$. angulata on wound healing process has not been studied yet. The aim of this research are to determine the effects of L. angulata bark extracts on wound healing of mouse skin and its influence on the localization of FGF2. One percent of $L$. angulata bark extracts (P1\%) on day 7 accelerated wound closure at value of $94.66 \%$, Deep Contraction Index and Superficial Contraction Index (DCI dan SCI) of 0.96 and 0.1, epidermis index (Ei) and remodelling index (Ri) of 1.55 and 0.81 . L. angulata bark extracts stimulates the synthesis of FGF2 earlier (3rd day) than the postive control group (5th day). FGF2 in P1\% group was detected in epithelial cells in the hair follicles, fibroblasts cell in granulation tissue and epithelial cells in the epidermis. In the positive control group FGF2 was detected in epithelial cell of hair follicle, while in the negative control group, FGF2 undetectable. FGF2 in P1\% group detected earlier than the positive control, showing the process of proliferation in $\mathrm{P} 1 \%$ accelerated. The results confirmed that the $L$. angulata bark extracts accelerated the wound healing in proliferation phase and influence localization of FGF2 in the wound area.
\end{abstract}

Key words: Leea angulata, wound healing, FGF2, immunohistochemistry

\section{PENDAHULUAN}

Luka merupakan kerusakan sebagian atau keseluruhan jaringan sehingga dapat mengganggu fungsi kulit (Enoch 2007). Jenis luka ada bermcammacam, diantaranya yang termasuk luka mekanik adalah luka insisi/sayat, luka memar, luka bakar, dan luka tusuk. Luka dapat juga disebabkan oleh zat kimia, radiasi, atau sengatan listrik dan digolongkan ke dalama luka non mekanik. Luka juga dapat digolongkan berdasarkan kedalaman dan luasnya (stadium 1-IV) serta berdasarkan waktu penyembuhan yaitu luka akut dan luka kronis. Luka dapat menimbulkan rasa nyeri, infeksi, dan menimbulkan bekas luka, oleh karena itu luka harus segera ditangani agar proses penyembuhan luka berlangsung normal dan dapat mencegah munculnya berbagai efek luka (Suriadi 2004).

Penyembuhan luka merupakan suatu proses dinamis dan kompleks yang terdiri dari beberapa tahap untuk mengembalikan struktur dan fungsi jaringan

*Penulis korespondensi:

E-mail: aang@sith.itb.ac.id yang luka. Tahapan dalam proses penyembuhan luka adalah inflamasi, proliferasi, dan remodelling (Wild et al. 2010). Salah satu faktor tumbuh yang sangat penting dalam proses penyembuhan luka adalah Fibroblast growth factor-2 (FGF2).

FGF2 merupakan salah satu dari tiga anggota famili FGF yang memiliki peran sangat penting dalam penyembuhan luka pada kulit. FGF-2 berperan dalam pembentukan jaringan granulasi, reepitelialisasi, dan remodelling (Barrientos et al. 2008). Beberapa penelitian sebelumnya secara in vitro telah menunjukkan bahwa FGF-2 menstimulasi migrasi dan proliferasi sel fibroblas (Ornitz dan Itoh 2015), meningkatkan pergerakan keratinosit selama reepitelialisasi (Sogabe et al. 2006), serta mengatur sintesis dan deposisi kolagen yang merupakan salah satu komponen utama dari luka akut jaringan ikat (Shi et al. 2013). Penelitian tentang FGF2 pada luka telah banyak dilakukan, bahkan FGF2 sudah dibuat dalam bentuk spray dan sudah di pasarkan sejak tahun 2001 di Jepang dan China (Spaccapelo 2016). FGF2 digunakan karena dapat mencegah timbulnya bekas luka (Akita et al. 2011). Besarnya 
peran FGF2 pada penyembuhan luka mendorong penelitian tentang agen yang dapat menstimulasi sintesis FGF2. Kutlu et al. (2013) telah membuktikan bahwa FGF2 yang distimulasi oleh minyak lavender dapat mempercepat dan menghilangkan luka sayat pada tikus. Penelitian secara in vitro yang dilakukan oleh Rashid et al. (2008) juga menunjukkan bahwa sintesis FGF2 dapat distimulasi oleh vitamin E pada sel fibroblas. Berdasarkan hasil penelitian tersebut, diketahui bahwa sintesis FGF2 pada jaringan luka distimulasi oleh senyawa tertentu yang terkandung dalam obat luka.

Di daerah Lombok (Lombok Utara), kulit batang L. angulata sering dimanfaatkan oleh masyarakat Suku Sasak sebagai obat penyembuh luka. Menurut pengakuan masyarakat Suku Sasak, penggunaan kulit batang $L$. angulata dapat mengurangi rasa sakit, mempercepat penutupan luka dan tidak menimbulkan bekas luka. Di Indonesia, penelitian mengenai potensi tumbuhan L. angulata sebagai obat luka belum dilakukan, namun dua tumbuhan dari genus yang sama telah dimanfaatkan sebagai obat luka di India. Dewanjee et al. (2013) membuktikan bahwa ekstrak akar L. macrophylla memiliki aktifitas anti inflamasi. Tumbuhan tersebut juga digunakan secara tradisional di India sebagai obat penyembuhan luka (Josh et al. 2016). Nair et al. (2014) juga membuktikan penyembuhan luka dan aktifitas anti inflamasi serta toksisitas ekstrak daun Leea asiatica yang mampu mempercepat penutupan luka (wound contraction) dan mempercepat fase inflamasi pada luka.

Berdasarkan kearifan lokal daerah Lombok, maka ekstrak kulit batang L. angulata dari daerah Tanjung, Lombok Utara akan diuji untuk dapat membuktikan perannya sebagai obat penyembuh luka. Penelitian ini dilakukan untuk mengkaji peran ekstrak kulit batang $L$. angulata dalam proses penyembuhan luka sayat pada kulit mencit (Mus musculus) berdasarkan penutupan luka (wound contraction), ketebalan epidermis, dan tutupan kolagen, serta pengaruhnya terhadap lokalisasi fibroblast growth factor-2 (FGF-2) pada jaringan luka.

\section{BAHAN DAN METODE}

Bahan. Kulit batang L. angulata yang berasal dari Lombok Utara, NTB. Kulit batang L. angulata dikeringkan kemudian digiling hingga berbentuk serbuk. Selanjutnya, serbuk tersebut diekstraksi menggunakan pelarut air dengan cara $50 \mathrm{~g}$ serbuk dilarutkan kedalam 1 liter akuades. Campuran tersebut dipanaskan selama 3 jam kemudian disaring dan diliofilisasi menggunakan freeze-dryer (Abdulla et al. 2010). Serbuk hasil freeze-dry kemudian dianalisis menggunakan GCMS serta digunakan untuk membuat larutan ekstrak dengan tiga konsentrasi berbeda yaitu 0.5, 1.0, dan 1.5\% (w/v) mengacu Babu et al. (2011).

Hewan Uji. Hewan yang digunakan dalam penelitian ini adalah mencit (Mus musculus) jantan galur Swiss Webster berumur 8 minggu, dengan berat badan berkisar antara 28-30 gram. rancangan perobaan berupa Rancangan Acak Kelompok (RAK), yang terdiri dari empat kelompok berdasarkan waktu pengamatan yaitu kelompok hari ke-1, 3, 5, dan 7. Pada masing-masing kelompok tersebut terdapat lima perlakuan yaitu tiga perlakuan dengan pemberian ekstrak kulit batang L. angulata secara topikal pada daerah luka dengan konsentrasi ekstrak 0.5, 1.0, dan $1.5 \%$, serta dua perlakuan sebagai kontrol yang terdiri dari kontrol positif yaitu dengan pemberian vitamin E dan kontrol negatif hanya diberikan akuades (tanpa ekstrak). Jumlah mencit yang digunakan untuk setiap perlakuan adalah sebanyak 5 ekor.

Perlakuan. Pembuatan luka pada tiap mencit diawali dengan anestesi menggunakan ketamine (100 $\mathrm{mg} / \mathrm{ml})$ dan xylazine $(20 \mathrm{mg} / \mathrm{ml})$ secara intraperitonial. Punggung dibersihkan dengan alkohol $70 \%$ kemudian luka sayat dibuat sejajar dengan tulang belakang menggunakan pisau bedah no. 15 yang dimodifikasi dengan penambahan holder agar kedalam luka dan panjang luka seragam untuk semua kelompok perlakuan. Sayatan paravertebral ini berjarak $1 \mathrm{~cm}$ dari tulang belakang dengan panjang luka $15 \mathrm{~mm}$ dan kedalaman $1 \mathrm{~mm}$ dari permukaan kulit punggung (Kallioniemi 2010) (Gambar 1). Selanjutnya mencit

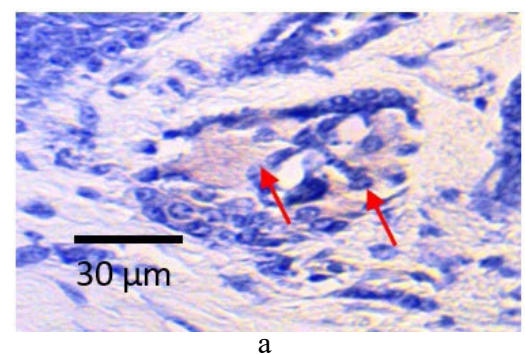

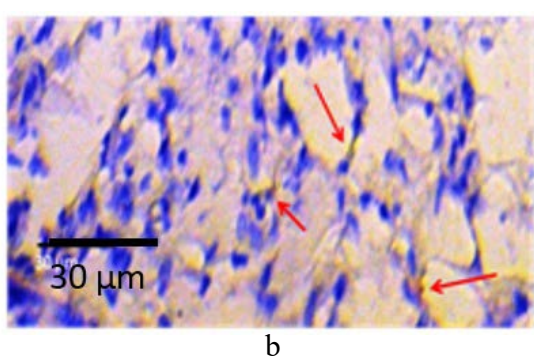

b

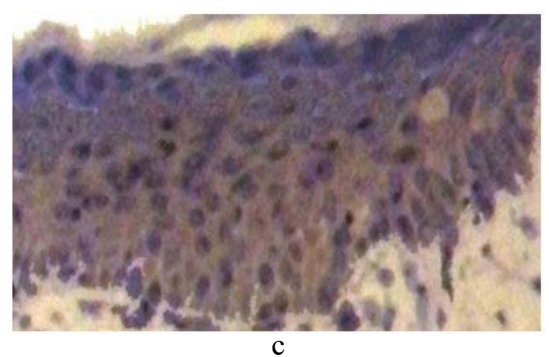

$\mathrm{C}$

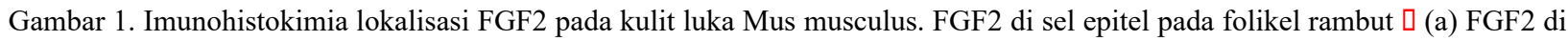
sel fibroblast pada jaringan granulasi $\mathrm{Q}$, (b) perbesaran 200x. FGF2 di sel epitel epidermis, (C) perbesaran 100x 
diberi perlakuan berupa pemberian ekstrak $L$. angulata dengan konsentrasi berbeda $(0.5,1.0,1.5 \%$, vitamin E dan tanpa ekstrak sebagai kontrol). Aplikasi topikal dilakukan dua kali sehari (pukul 09.00 am dan 16.00 pm) masing-masing sebanyak $75 \mu 1$ selama 7 hari.

Penentuan Konsentrasi Optimum Ekstrak. Untuk menentukan konsentrasi optimum ekstrak kulit batang $L$. angulata, dilakukan dengan menghitung persentase penutupan luka (wound contraction) secara morfologi, pada semua kelompok perlakuan pada hari ke-1, 3, 5, dan 7. Pengukuran panjang luka menggunakan kertas millimeter blok transparan. Persentase penutupan luka dihitung menggunakan persamaan Naik et al. (2009):

$$
\underset{\text { penutupan luka }}{\text { Persentase }}=\frac{\text { area yang menutup }}{\text { total area luka }} \times 100
$$

Persentase penutupan luka paling tinggi pada hari ke-7 adalah pada kelompok ekstrak kulit batang $L$. angulata $1 \%$. Dengan demikian, jaringan kulit luka dari konsentrasi tersebut selanjutnya dianalisis secara histologi.

Analisis Histologi. Jaringan kulit difiksasi dalam larutan Bouin dan dilanjutkan dengan metode paraffin. Jaringan disayat dengan ketebalan $6 \mu \mathrm{m}$ dan diwarnai dengan pewarnaan Mallory-Azan. Paramater yang diukur pada sediaan histologi terdiri dari tiga parameter yang diukur menggunakan software ImageJ 1.49 for Windows berdasarkan profil wound contraction Sayatan Histologi (Gambar 2). Parameter tersebut adalah:

a) Deep Contraction Index (DCI) dan Superficial Contraction Index (SCI), yang dikuantifikasi menggunakan persamaan-persamaan berikut:

$$
\mathrm{SCI}=(\mathrm{L}-\mathrm{S}) / \mathrm{L} \quad \mathrm{DCI}=(\mathrm{N}-\mathrm{D}) / \mathrm{N}
$$

Wound contraction index $(\mathrm{WCI})=\mathrm{SCI}+\mathrm{DCI}$

b) Indeks epidermis, dikuantifikasi dengan persaman berikut:

$$
\underset{\text { Indeks ketebalan }}{\text { epidermis }}=\frac{\begin{array}{c}
\text { ketebalan epidermis } \\
\text { daerah luka }
\end{array}}{\begin{array}{c}
\text { ketebalan epidermis } \\
\text { daerah tidak luka }
\end{array}}
$$

c) Indeks remodelling (diukur melalui tutupan kolagen), dikuantifikasi dengan persaman berikut:

$$
\underset{\text { Indeks }}{\text { remodelling }}=\frac{\begin{array}{c}
\text { tutupan kolagen } \\
\text { daerah luka }
\end{array}}{\begin{array}{c}
\text { tutupan kolagen } \\
\text { daerah tidak luka }
\end{array}}
$$

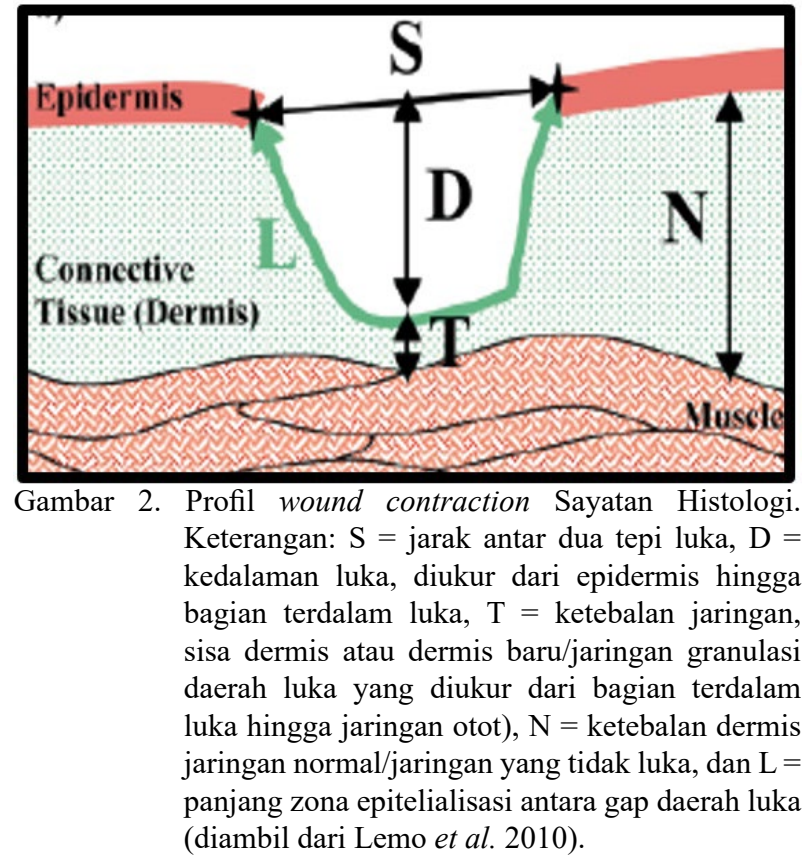

Imunohistokimia (IHC). Kehadiran FGF-2 pada sayatan dideteksi dengan menggunakan HRP Substrat Mixture dari Biogenex dan selanjutnya dilakukan counterstaining menggunakan hematoksilin. Sebagai kontrol negatif, antibodi-anti FGF-2 digantikan oleh normal serum (Santa Cruz). Reaksi positif terhadap FGF-2 ditandai dengan munculnya warna kecoklatan pada sayatan.

Analisis Data. Seluruh data hasil pengukuran penutupan luka (wound contraction) dan data histologi kemudian dianalisis secara statistik, menggunakan software SPSS 16.0 for windows. Derajat signifikansi data dinilai dengan menggunakan One Way ANOVA jika data berdistribusi normal dan homogen, dilanjutkan dengan uji lanjutan (post-hoc test) tukey dengan nilai P. 5\%.

\section{HASIL}

Hasil GCMS. Analisis fitokimia ekstrak $L$. angulata mengandung beberapa senyawa aktif antara lain Cyclobarbital (20.3\%), vitamin E (16.1\%), Benzohidroquinoline (5.93\%), Cyclotrisiloxane $(0.88 \%)$, Benzenediol (0.33\%), 1H-Indol 1-methyl2-phenyl (5.71\%), dan Benzenetriol (4.24\%) (Tabel 1).

Penutupan Luka (wound contraction) secara Morfologi. Hasil penutupan luka secara morfologi dapat dilihat pada Tabel2. Berdasarkan Tabel 2 tersebut dapat diketahui bahwa persentase penutupan luka terus bertambah dari hari ke-1 hingga hari ke-7 pada seluruh perlakuan. Data studi pendahuluan ini menunjukkan bahwa luka akan sembuh pada hari ke-7 pada kelompok perlakuan $\mathrm{P} 1 \%$. Hal ini menunjukkan terjadinya proses penyembuhan luka karena adanya perbaikan 
dan pembentukan jaringan baru pada daerah luka. Persentase penutupan luka pada kelompok P $1 \%$ mulai hari ke-1 hingga hari ke-7 perlakuan menunjukkan nilai yang lebih tinggi secara signifikan $(\mathrm{P}<0.05)$ dibandingkan dengan nilai pada semua kelompok. Persentase penutupan luka kelompok P.0.5\% dan P. $1.5 \%$ berbeda siginifikan dengan kelompok K- dan tidak berbeda signifikan dengan $\mathrm{K}+$.

Deep Contraction Index (DCI) dan Superficial Contraction Index (SCI). Hasil pengukuran DCI dan SCI dapat dilihat pada Tabel 3. Berdasarkan data pada Tabel 3 dapat diketahui bahwa nilai SCI pada semua perlakuan terus menurun dari hari 1 hingga hari ke 7. Nilai SCI pada hari ke-1 dan ke-3 masih tinggi tidak berbeda signifikan pada semua kelompok perlakuan. Pada hari ke-5, terdapat perbedaan secara signifikan antara kelompok P.1\% dengan kelompok Kontrol negatif $(\mathrm{P}<0.05)$, dan tidak berbeda nyata dengan kelompok kontrol positif. Indeks DCI pada kelompok P.1\% hari ke-3 paling tinggi secara signifikan dengan kelompok kontrol $(\mathrm{P}<0.05)$. Pada hari ke-5 dan ke-7 nilai indeks DCI pada kelopok P.1\% lebih tinggi dan berbeda secara signifikan dibandingkan dengan kelompok kontrol $(\mathrm{P}<0.05)$.

Indeks Epidermis. Hasil pengukuran indeks epidermis dapat dilihat pada Tabel 4. Data pada Tabel 4 menunjukkan kecenderungan yang sama pada seluruh perlakuan yaitu indeks epidermis meningkat mulai dari hari ke-1 dan mencapai puncak pada hari ke-3, kemudian mengalami penurunan hingga hari ke-7. Hasil uji statistik menunjukkan bahwa pada hari ke tiga dan ke lima indeks epidermis pada kelompok $\mathrm{P} 1 \%$

Tabel 1. Tabel senyawa hasil uji GCMS ekstrak kulit batang Leea angulata

\begin{tabular}{|c|c|c|c|}
\hline Area (\%) & Nama zat & $\begin{array}{l}\text { Rumus } \\
\text { molekul }\end{array}$ & Fingsi \\
\hline 20.3 & Cyclobarbital & $\mathrm{C}_{12} \mathrm{H}_{16} \mathrm{~N}_{2} \mathrm{O}_{3}$ & Anestesi \\
\hline 15.38 & Vitamin E & - & Antioksidan \\
\hline 5.93 & $\begin{array}{l}\text { Benzo[h]quinoline, } \\
\text { 2,4-dimethyl- }\end{array}$ & $\mathrm{C}_{15} \mathrm{H}_{13} \mathrm{~N}$ & Antioksidan \\
\hline 5.71 & $\begin{array}{l}\text { 1H-Indole, } \\
\text { 1-methyl-2- } \\
\text { phenyl- }\end{array}$ & $\mathrm{C}_{15} \mathrm{H}_{13} \mathrm{~N}$ & Antimikroba \\
\hline 4.24 & 1,2,3-Benzenetriol & $\mathrm{C}_{6} \mathrm{H}_{3}(\mathrm{OH})_{3}$ & $\begin{array}{l}\text { Antiseptik dan } \\
\text { antibakteri }\end{array}$ \\
\hline 0.82 & $\begin{array}{l}\text { Cyclotrisiloxane, } \\
\text { hexamethyl- }\end{array}$ & $\mathrm{C}_{6} \mathrm{H}_{18} \mathrm{O}_{3} \mathrm{Si}_{3}$ & Antioksidan \\
\hline 0.33 & 1,2-Benzenediol & $\mathrm{C}_{6} \mathrm{H}_{6} \mathrm{O}_{2}$ & Antioksidan \\
\hline
\end{tabular}

berbeda nyata dibandingkan dengan kelompok kontrol positif maupun kelompok kontrol negatif $(\mathrm{P}<0.05)$. Hal ini menunjukkan bahwa pada kelompok P.1\% terjadi proses perbaikan lapisan epidermis luka yang lebih baik dibandingkan kelompok perlakuan lainnya. Kelompok P. 1\% pada hari ke-7 menunjukkan indeks epidermis mendekati 1 , nilai yang paling rendah dibandingkan kelompok kontrol.

Indeks Remodelling. Hasil indeks remodelling dapat dilihat pada Tabel 5. Pada penelitian ini, indeks remodelling dari hari ke-3 hingga hari ke-7 mengalami peningkatan pada semua kelompok. Nilai kelompok P.1\% tertinggi secara signifikan pada hari ke-7 dibandingkan dengan kelompok kontrol negatif $(\mathrm{P}<0.05)$. Indeks remodelling hari ke-7 pada kelompok P. $1 \%$ yaitu 0.81 .

Tabel 3. SCI dan DCI pada masing-masing kelompok dan waktu perlakuan

\begin{tabular}{|c|c|c|c|c|}
\hline $\begin{array}{l}\text { Kontraksi/ } \\
\text { kelompok } \\
\text { perlakuan }\end{array}$ & & Har & i ke- & \\
\hline SCI & 1 & 3 & 5 & 7 \\
\hline $\mathrm{K}+$ & $0.50 \pm 0.12^{\mathrm{a}}$ & $0.29 \pm 0.07^{\mathrm{a}}$ & $0.16 \pm 0.08^{\mathrm{ab}}$ & $0.11 \pm 0.15^{\mathrm{a}}$ \\
\hline P.1\% & $0.46 \pm 0.04^{\mathrm{a}}$ & $0.22 \pm 0.12^{\mathrm{a}}$ & $0.10 \pm 0.09^{\mathrm{a}}$ & $0.10 \pm 0.07^{\mathrm{a}}$ \\
\hline $\mathrm{K}-$ & $0.31 \pm 0.18^{\mathrm{b}}$ & $0.28 \pm 0.06^{\mathrm{a}}$ & $0.19 \pm 0.17^{b}$ & $0.09 \pm 0.13^{\mathrm{a}}$ \\
\hline DCI & & & & \\
\hline $\mathrm{K}+$ & $0.22 \pm 0.11^{\mathrm{a}}$ & $0.51 \pm 0.13^{\mathrm{ab}}$ & $0.80 \pm 0.05^{\mathrm{b}}$ & $0.89 \pm 0.02^{\mathrm{b}}$ \\
\hline P.1\% & $0.31 \pm 0.03^{\mathrm{a}}$ & $0.64 \pm 0.12^{\mathrm{a}}$ & $0.90 \pm 0.05^{\mathrm{a}}$ & $0.96 \pm 0.02^{\mathrm{a}}$ \\
\hline $\mathrm{K}-$ & $0.48 \pm 0.18^{b}$ & $0.49 \pm 0.05^{\mathrm{b}}$ & $0.85 \pm 0.06^{\mathrm{ab}}$ & $0.91 \pm 0.03^{\mathrm{c}}$ \\
\hline $\begin{array}{c}\text { Rerata } \pm \\
\text { menunj } \\
5 \%, \mathrm{n}= \\
\text { masing } \\
\text { angulat } \\
\text { negarif }\end{array}$ & $\begin{array}{l}9 \text { pita sayat } \\
\text { waktu peng } \\
a 1 \% \text {, kontr } \\
\mathrm{K}(-)=\text { tanpa }\end{array}$ & $\begin{array}{l}\text { n per kelompc } \\
\text { matan. } \mathrm{P} .1 \% \\
1 \text { positif } \mathrm{K}(+) \\
\text { pemberian ek }\end{array}$ & $\begin{array}{l}\text { a huruf ya } \\
\text { kan uji } U(M c \\
\text { k perlakuan } \\
=\text { ekstrak ku } \\
=\text { vitamin } \mathrm{E} \\
\text { trak }\end{array}$ & $\begin{array}{l}\text { ng berbeda } \\
n n \text {-Whitney) } \\
\text { ada masing- } \\
\text { it batang } L \text {. } \\
\text { dan kontrol }\end{array}$ \\
\hline
\end{tabular}

Tabel 4. Indeks epidermis pada masing-masing kelompok dan waktu perlakuan

\begin{tabular}{cccc}
\hline \multirow{2}{*}{ Hari ke- } & \multicolumn{3}{c}{ Kelompok perlakuan } \\
\cline { 2 - 4 } & $\mathrm{K}+$ & $\mathrm{P} .1 \%$ & $\mathrm{~K}-$ \\
\hline 1 & $0.83 \pm 0.39^{\mathrm{a}}$ & $0.78 \pm 0.47^{\mathrm{a}}$ & $1.21 \pm 0.74^{\mathrm{b}}$ \\
3 & $2.97 \pm 0.94^{\mathrm{b}}$ & $2.42 \pm 0.62^{\mathrm{a}}$ & $3.97 \pm 1.35^{\mathrm{c}}$ \\
5 & $2.73 \pm 0.50^{\mathrm{b}}$ & $2.06 \pm 0.60^{\mathrm{a}}$ & $3.01 \pm 1.21^{\mathrm{b}}$ \\
7 & $1.75 \pm 0.40^{\mathrm{a}}$ & $1.55 \pm 0.68^{\mathrm{a}}$ & $1.62 \pm 0.45^{\mathrm{a}}$ \\
\hline
\end{tabular}

Rerata \pm SD yang diikuti denga huruf yang berbeda menunjukkan beda nyata berdasarkan uji U (Mann-Whitney) $5 \% ; n=9$ pita sayatan per kelompok perlakuan pada masingmasing waktu pengamatan. P. $1 \%=$ ekstrak kulit batang $L$. angulata $1 \%$, kontrol positif $\mathrm{K}(+)=$ vitamin $\mathrm{E}$, dan kontrol negarif $\mathrm{K}(-)=$ tanpa pemberian ekstrak

Tabel 2. Persentase penutupan luka pada masing-masing kelompok dan waktu perlakuan

\begin{tabular}{lcccc}
\hline \multirow{2}{*}{ Kelompok perlakuan } & \multicolumn{4}{c}{ Penutupan luka (\%) hari ke- } \\
\cline { 2 - 5 } & 1 & 3 & 5 & 7 \\
\hline P. $0.5 \%$ & $13.33 \pm 4.71^{\mathrm{b}}$ & $41.33 \pm 2.98^{\mathrm{c}}$ & $64.00 \pm 3.65^{\mathrm{bc}}$ & $84.00 \pm 3.65^{\mathrm{c}}$ \\
P. $1 \%$ & $26.66 \pm 4.71^{\mathrm{c}}$ & $53.33 \pm 4.71^{\mathrm{d}}$ & $70.66 \pm 3.65^{\mathrm{c}}$ & $94.66 \pm 5.57^{\mathrm{d}}$ \\
P. $1.5 \%$ & $17.33 \pm 3.65^{\mathrm{b}}$ & $37.33 \pm 3.65^{\mathrm{bc}}$ & $58.66 \pm 5.57^{\mathrm{b}}$ & $72.00 \pm 2.98^{\mathrm{ab}}$ \\
K+ (Vit. E) & $10.66 \pm 3.65^{\mathrm{b}}$ & $33.33 \pm 4.71^{\mathrm{ab}}$ & $61.33 \pm 2.98^{\mathrm{b}}$ & $80.00 \pm 4.71^{\mathrm{bc}}$ \\
K- & $2.66 \pm 5.96^{\mathrm{a}}$ & $26.66 \pm 4.71^{\mathrm{a}}$ & $44.00 \pm 3.65^{\mathrm{a}}$ & $66.66 \pm 4.71^{\mathrm{a}}$ \\
\hline
\end{tabular}

Rerata \pm SD yang diikuti dengan huruf yang berbeda menunjukkan beda nyata berdasarkan uji Tukey 5\%, $\mathrm{n}=5$ Mus musculus per kelompok perlakuan pada masing-masing waktu pengamatan. P. $0.5 \%=$ ekstrak kulit batang L. angulata $0.5 \%$, P. $1 \%=$ ekstrak kulit batang $L$. angulata $1 \%$, P. $1.5 \%=$ ekstrak kulit batang $L$. angulata $1.5 \%$ kontrol positif $\mathrm{K}(+)=$ vitamin E, dan kontrol negarif $\mathrm{K}(-)=$ tanpa pemberian ekstrak 
Tabel 5. Indeks remodelling pada masing-masing kelompok dan waktu perlakuan

\begin{tabular}{|c|c|c|c|}
\hline \multirow{2}{*}{ Hari ke- } & \multicolumn{3}{|c|}{ Perlakuan } \\
\hline & $\mathrm{K}+$ & P.1\% & K- \\
\hline 3 & $0.28 \pm 0.22^{\mathrm{a}}$ & $0.17 \pm 0.15^{\mathrm{a}}$ & $0.15 \pm 0.19^{\mathrm{a}}$ \\
\hline 5 & $0.24 \pm 0.18^{\mathrm{a}}$ & $0.36 \pm 0.14^{\mathrm{a}}$ & $0.34 \pm 0.24^{\mathrm{a}}$ \\
\hline 7 & $0.52 \pm 0.35^{\mathrm{ab}}$ & $0.81 \pm 0.23^{\mathrm{b}}$ & $0.44 \pm 0.19^{\mathrm{a}}$ \\
\hline \multicolumn{4}{|c|}{$\begin{array}{l}\text { Rerata } \pm \text { SD yang diikuti denga huruf yang berbeda } \\
\text { menunjukkan beda nyata berdasarkan uji Tukey } 5 \%, \mathrm{n}=9 \\
\text { pita sayatan per kelompok perlakuan pada masing-masing } \\
\text { waktu pengamatan. P. } 1 \%=\text { ekstrak kulit batang } L . \text { angulata } \\
1 \% \text {, kontrol positif } \mathrm{K}(+)=\text { vitamin } \mathrm{E} \text {, dan kontrol negarif } \\
\mathrm{K}(-)=\text { tanpa pemberian ekstrak }\end{array}$} \\
\hline
\end{tabular}

Lokalisasi FGF2. Berdasarkan kehadiran FGF2 pada hari pengamatan (hari 3, 5, dan 7), maka dapat dibuat suatu diagram lokalisasi FGF2 seperti pada Gambar 3. Hasil IHC menunjukkan FGF2 pada kelompok P1\% terdeteksi pada hari ke-3, hari ke-5 dan hari ke-7. Pada hari ke-3 FGF2 ditemukan disel epitel pada folikel rambut, hari ke-5 ditemukan di sel epitel pada folikel rambut, sel fibroblas pada jaringan granulasi dan sel epitel pada lapisan epidermis, sedangkan pada hari ke-7 hanya ditemukan di sel epitel pada folikel rambut. Pada kelompok kontrol positif FGF2 ditemukan pada hari ke-5 dan hari ke-7 di sel epitel pada folikel rambut saja, sedangkan pada kelompok kontrol negatif, FGF2 tidak terdeteksi (Gambar 1).

\section{PEMBAHASAN}

Proses penyembuhan luka merupakan proses yang bertujuan untuk mengembalikan struktur dan fungsi jaringan. Penutupan luka merupakan salah satu hal penting dalam penyembuhan luka. Pada penelitian ini ekstrak $L$. angulata $1 \%$ mempercepat penutupan luka secara morfologi dibandingkan kelompok kontrol (Tabel 2). Penutupan luka secara morfologi adalah kombinasi dari pengurangan celah luka (SCI) dan pengurangan kedalaman luka (DCI). Nilai SCI terus berkurang sejak hari ke 1 hingga hari ke-7, menunjukkan bahwa jarak antara 2 dinding luka terus berkurang setiap hari pengamatan. Perbedaan signifikan terjadi pada hari ke-5 dengan nilai SCI terbaik ditunjukka oleh kelompok P1\%. Hal ini menunjukkan bahwa kandungan pada ekstrak kulit batang $L$. angulata dapat membantu penutupan luka secara superficial dengan mengurangi jarak antar dua dinding luka setelah hari ke 3 hingga hari ke 5 .

Ektrak kulit batang L. angulata tidak hanya mempercepat penutupan bagian permukaan luka, tetapi juga mengurangi kedalaman luka secara signifikan. Nilai DCI tertinggi pada kelompok P1\% menunjukkan bahwa ekstrak $L$. angulata mengurangi kedalaman luka degan cara mempercepat pembentukan jaringan granulasi (Tabel 3). Menurut Lemo et al. (2010), pembentukan jaringan granulasi berperan mengisi kekosongan jaringan pada luka. Berdasarkan hasil penutupan luka secara morfologi dan histologi tersebut dapat diketahui bahwa pemberian ekstrak kulit batang

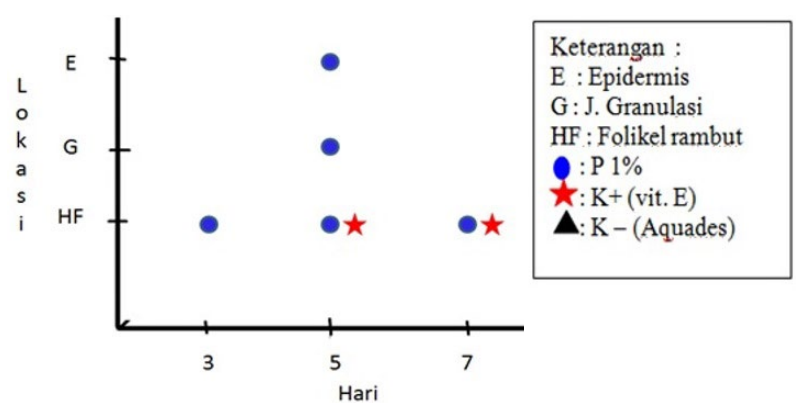

Gambar 3. Lokalisasi FGF2 pada masing-masing kelompok dan waktu perlakuan. Keterangan: FGF2 terdeteksi pada perlakuan $1 \%$ dan kontrol + (vit E), sedangkan pada kontrol - (akuades) tidak terdeteksi adanya FGF2. Pada perlakuan 1\%, FGF 2 mulai terdeteksi pada hari ke 3 hingga hari ke 7 pada 3 tempat berbeda, sedangkan pada kontrol +, FGF2 mulai terdeteksi pada hari ke 5 hingga hari ke 7

L. angulata dapat mempercepat penutupan luka. Hasil yang serupa juga ditemukan dari penelitian Nair et al. (2014) secara in vivo, bahwa pemberian dari ekstrak Leea asiatica dapat mempercepat penyembuhan luka.

Reepitelisasi sangat penting dalam mencegah kehilangan air dan terjadingan infeksi pada luka. Kelompok P.1\% pada hari ke-7 menunjukkan indeks epidermis mendekati 1, nilai yang paling rendah dibandingkan kelompok kontrol. Indeks epidermis sebesar 1 menurut Lemo et al. (2010) menunjukkkan bahwa ketebalan epidermis luka sama dengan ketebalan epidermis normal (tidak luka). Dengan demikian dapat dikatakan bahwa penggunaan ekstrak L. angulata dapat mempercepat normalisasi ketebalan epidermis.

Pada penelitian ini, tutupan kolagen tertinggi ditunjukkan oleh kelompok P.1\% pada hari ke-7 dibandingkan dengan kelompok kontrol (Tabel 5). Hasil penelitian ini serupa dengan hasil penelitian Triyono dan Bambang (2005) yang membuktikan tutupan kolagen pada luka eksisi tikus meningkat pada hari ke-5 setelah pemberian levobupivakain, sedangkan penelitian oleh Afrianti (2014) menemukan bahwa tutupan kolagen meningkat pada hari ke-8 pada luka mencit setelah pemberian ekstrak Ageratum conyzoides. Nilai tutupan kolagen yang mendekati 1 (satu) pada kelompok P.1\% menunjukkan bahwa luka lebih cepat memasuki tahap maturasi dan lebih cepat sembuh dibandingkan dengan kelompok kontrol. Hasil sayatan histologi kelompok P1\% (Gambar 4) memperlihatkan tutupan kolagen yang lebih baik dibandingkan kontrol. Dengan demikian jaringan granulasi hampir tertutup sempurna dengan kolagen dan relatif sulit dibedakan dengan daerah yang tidak luka pada kelompok P.1\%.

Sitokin dan growth factor terlibat dalam proses penyembuhan luka baik pada tahap inflamasi, proliferasi dan remodelling (Wild et al. 2010). Pade penelitian ini, ekstrak L. angulata dapat menstimulus sintesis FGF2 dibandingkan dengan kontrol. Hal ini menunjukkan bahwa jaringan luka pada perlakuan ekstrak L. angulata memasuki tahap proliferasi lebih cepat sehingga masa penyembuhan luka lebih 
$\mathrm{K}+$

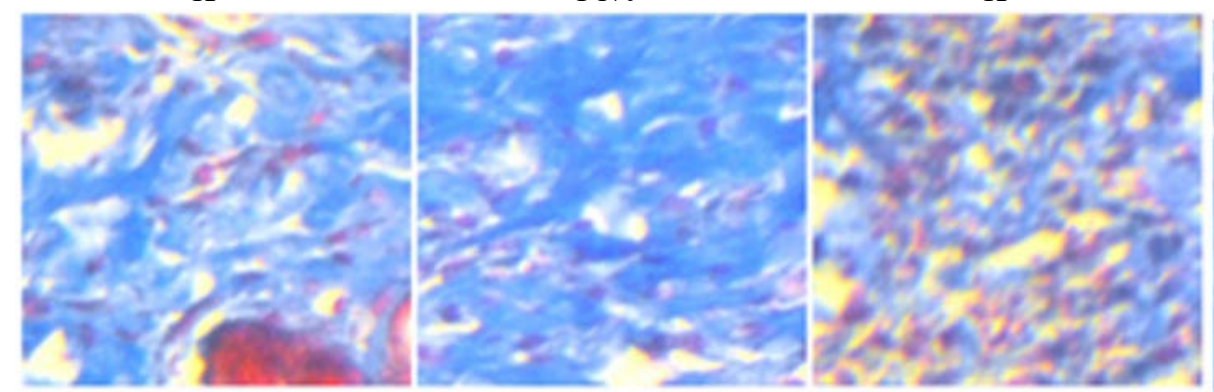

Gambar 4. Tutupan kolagen pada hari ke-7 setelah luka. Tutupan kolagen (warna biru), tutupan kolagen dengan pemberian ekstrak kulit batang L. angulata (P1\%) lebih rapat dibandingkan dengan kontrol. Pewarnaan Mallory-Azzan x 200

singkat. Proses penyembuhan yang lebih cepat juga ditunjukkan oleh periode epitelisasi pada perlakuan P1\% paling cepat yakni selama 7 hari.

FGF2 terdeteksi di sel epitel pada folikel rambut, sel epitel pada lapisan epidermis dan di sel fibroblas pada jaringan granulasi. Kehadiran FGF2 pada berbagai lokasi tersebut berkaitan dengan fungsinya dalam rangka proliferasi sel fibroblas, sel endotel, dan sel epitel folikel rambut serta dalam migrasi epitel. Kehadiran FGF2 pada sel epitel folikel rambut tersebut berfungsi untuk menstimulasi pertumbuhan rambut dan adanya folikel rambut di sekitar luka merupakan salah satu indikator perbaikan jaringan luka (Lemo et al. 2010). Hasil penelitian Lin et al. (2015) juga menunjukkan bahwa FGF2 dapat menstimulasi pertumbuhan rambut mencit (jumlah dan panjang rambut) dengan menginduksi fase anagen pada folikel rambut melalui jalur $\beta$-catenin dan Shh (Sonic hedgehog). Namun pada penelitian ini, jumlah folikel rambut tidak diamati.

FGF2 terdeteksi di sel epitel pada lapisan epidermis. Keberadaan FGF2 pada lapisan epidermis kemungkinan berperan dalam menstimulasi migrasi dan proliferasi sel epitel, yang ditunjukkan oleh indeks epidermis paling rendah pada P.1\% yaitu sebesar 1.55 dibandingkan dengan kontrol. Diduga pemberian ekstrak $L$. angulata mempercepat proses reepitelialisasi pada jaringan luka. FGF2 juta terdeteksi pada jaringan granulasi, sehingga dapat berperan dalam menstimulasi pembentukan jaringan granulasi. Hal ini didukung pula oleh hasil DCI pada hari ke-7 yang menunjukkan nilai paling tinggi sebesar 0.96 dibandingkan dengan kontrol. Lokalisasi FGF2 pada penelitian ini berada di sel fibroblast pada jaringan granulasi, kemungkinan berkaitan dengan peran FGF2 dalam proliferasi fibroblas. Proliferasi fibroblast berhubungan dengan sintesis kolagen, hal ini didukung pula dengan nilai indeks remodelling tinggi pada hari ke-7 pada kelompok P.1\% yakni sebesar 0.81 . FGF2 yang tidak terdeteksi pada kontrol negatif $\mathrm{K}(-)$, kemungkinan lebih disebabkan oleh jumlah FGF2 yang sangat sedikit sehingga tidak dapat terdeteksi dengan metode IHC.

Kemampuan ekstrak L. angulata dalam menstimulus produksi FGF2 lebih awal pada 3 daerah yang berbeda diduga karena adanya kandungan senyawa aktif dalam ekstrak tersebut (Tabel 1). Pada penelitian ini, senyawa dari ekstrak kulit batang $L$. angulata yang diduga memberikan pengaruh pada penyembuhan luka yaitu senyawa berupa Cyclobarbital (20.3\%), senyawa bersifat antioksidan berupa vitamin E (16.1\%), Benzohidroquinoline (5.93\%), Cyclotrisiloxane (0.88\%), dan Benzenediol $(0.33 \%)$ (Thiele dan Mudiyanselage 2007; Nair et al. 2009). Senyawa lain yang juga diketahui memiliki aktifitas antimikroba yaitu 1 H-Indol 1-methyl-2phenyl (5.71\%), dan Benzenetriol (4.24\%) (Haile dan Dekebo 2013; Jahvad et al. 2014).

Cyclobarbital merupakan senyawa turunan barbiturat yang bersifat anestesik. Senyawa tersebut dapat menutupi membran akson sel saraf dan memblok kanal natrium sehingga menghentikan impuls saraf dan mencegah timbulnya rasa nyeri yang mempercepat proses penyembuhan luka (Hollmann dan Durieux 2000). Selain senyawa anestesi, ekstrak L. angulata juga mengandung senyawa $1 \mathrm{H}-\mathrm{Indol}$ 1-methyl-2-phenyl dan Benzenetriol yang bersifat antimikroba. Senyawa tersebut kemungkinan dapat mencegah terjadi infeksi pada luka. Tahap inflamasi berlangsung cepat dan luka segera memasuki tahap proliferasi, sehingga proses penyembuhan luka pada mencit lebih singkat yaitu selama 7 hari dibandingkan dengan kontrol.

Senyawa antioksidan juga dapat membantu proses penyembuhan luka. Menurut Srivastava (2011) senyawa antioksidan dapat berfungsi dalam penyembuhan luka karena dapat berperan sebagai Reactive Oxygen Species (ROS) scavanger. Aliyeva et al. (2004) menyatakan telah diketahui bahwa ROS pada saat luka jumlahnya meningkat memiliki efek yang berbahaya terhadap sel dan jaringan. Keberadaan radikal bebas ini mengakibatkan terjadinya stres oksidatif sehingga menimbulkan peroksidasi lemak, kerusakan DNA, dan inaktivasi enzim. Senyawa antioksidan dalam ekstrak kulit batang $L$. angulata kemungkinan berperan sebagai ROS scavenger yang melindungi jaringan dari kerusakan oksidatif. Dengan demikian, ketiadaan ROS memungkinkan jaringan luka melakukan perbaikan dengan mempercepat tahap proliferasi dalam penyembuhan luka secara signifikan dibuktikan dari indeks epidermis yang paling rendah dibandingkan kontrol. 
Salah satu antioksidan terbanyak yang dimilki oleh ekstrak kulit batang L. angulata adalah vitamin E. Vitamin E dalam ekstrak tersebut diduga memiliki pengaruh pada penyembuhan luka. Penelitian secara in vitro yang dilakukan oleh Rashid et al. (2008), membuktikan bahwa vitamin E dapat menstimulasi sel fibroblas untuk menghasilkan FGF2. Diduga pada penelitian ini vitamin E dalam ekstrak $L$. angulata sebesar $16.1 \%$ menstimulasi sintesis FGF2, sehingga FGF2 terdeteksi lebih awal pada hari ke-3 dibandingkan kelompok perlakuan lain dan pada hari ke-5 terdeteksi pada lokasi yang berbeda. Mekanisme vitamin E dari ekstrak $L$. angulata dalam sintesis FGF2 belum diketahui secara pasti. Dari hasil penelitian ini dapat disimpulkan bahwa ekstrak kulit batang L. angulata mempercepat penyembuhan luka pada tahap proliferasi berdasarkan persentase penutupan luka (wound contraction), indeks epidermis, dan indeks remodelling, serta dapat mempengaruhi lokalisasi dan kemunculan FGF2 pada daerah luka. Saran yang diberikan untuk penelitian selanjutnya tentang topik penelitian ini yakni perlu dilakukan studi mengenai jumlah FGF2 yang ada pada jaringan luka menggunakan metode Elisa.

\section{UCAPAN TERIMA KASIH}

Ucapan terima kasih kami sampaikan kepada Dirjen Perguruan Tinggi atas bantuan Beasiswa Pendidikan Pascasarjana Dalam Negeri (BPPDN) yang diterima selama menjalankan pendidikan di ITB.

\section{DAFTAR PUSTAKA}

Abdulla MA, Ahmed KA, Abu-Luhoom FA, Muhanid M. 2010 Role of Ficus deltoidea extract in the enhancement of wound healing in experimental rats. Biomedical Research 21:241-245.

Afrianti Ria. 2014. Pengamatan Serabut Kolagen Pada Proses Penyembuhan Luka Dalam Sediaan Krim Ekstrak Etanol Daun Bandotan (Ageratum conyzoides L.). Padang: Prosiding Seminar Nasional dan Workshop "Perkembangan Terkini Sains Farmasi dan Klinik IV".

Akita S, Akino K, Hirano A. 2011. Basic Fibroblast Growth Factor in Scarless Wound Healing. 2nd ed. Nagasaki: Wound healing society.

Aliyeva E, Umur S, Zafer E, Acigoz G. 2004. The effect of polylactide membranes on the Levels of reactive oxygen species in periodontal flaps during wound healing. Biomaterials 25:4633-4638.

Babu MK, Krishan BV, Murthy TEGK. 2011. Formulation and evaluation of Centella asiatica extract impregnated collagen dermal scaffolds for wound healing, International Journal of PharmTech Research 3:1382-1391.

Barrientos S, Stojadinovic O, Golinko MS, Harold Brem H, Tomic-Canic M. 2008. Growth factors and cytokines in wound healing. Wound Repair and Regeneration 16:585-601.

Dewanjee S, Dua TK, Sahu R. 2013. Potential anti-inflammatory effect of Leea macrophylla Roxb. leaves: a wild edible plant. Food Chem Toxicol 59:514e20.

Enoch S, Price P. 2007. Cellular, molecular, and biochemical differences in the pathophysiology of healing between acute wounds, chronic wounds and wounds in the aged. World Web Wound (serial online) 2007. Available at:http//www. worldwebwound.com [Date accessed: 8 April 2007]
Haile K, Dekebo A. 2013. Chemical composition and antimicrobial activity of haramaya propolis (Bee Glue), Ethiopia. IJPSR 4:734-740.

Hollmann MW, Durieux ME. 2000. Local Anesthetics and the Inflammatory Response A New Therapeutic Indication. Illinois: American Society of Anesthesiologists Inc.

Jadhav V, Kalase V, Patil, Poonam. 2014. GC-MS analysis of bioactive compounds in methanolic extract of Holigarna grahamii (wight) Kurz. International Journal of Herbal Medicine 2:35-39.

Joshi A, Prasad SK, Vinod Kumar Joshi VK, Hemalatha S. 2016. Phytochemical standardization, antioxidant, and antibacterial evaluations of Leea macrophylla: a wild edible plant. Journal of food and drug analysis 24:324-331.

Kallioniemi P. 2010. Effect of Plasminogen on Wound Healing in Mice, Master thesis project in Biotechnology, Chalmers University of Technology.

Kutlu AC, Dilek S, Seren GG, Oya S, Ferihan C. 2013. A Comparison Study of Growth Factor Expression following Treatment with Transcutaneous Electrical Nerve Stimulation, Saline Solution, Povidone-Iodine, and Lavender Oil in Wounds Healing. Evidence-Based Complementary and Alternative Medicine. Hindawi Publishing Corporation.

Lemo N, Marignac G, Reyez-Gomez E, Lilin T, Crosaz O, Ehrenfest MMD. 2010. Cutaneous reepithelialization and wound contraction after skin biopsies in rabbits: a mathematical model for healing and remodelling index, Veterinarski Arhiv 80:637-652.

Lin W, Xiang L, Shi H, Zhang J. 2015. Fibroblast Growth Factors Stimulate Hair Growth through $\beta$-Catenin and Shh Expression in C57BL/6 Mice. BioMed Research International. Hindawi Publishing Corporation.

Nair, Halehatty RP, Naik, Halehatty SBR, Ravikumar Naik, Thangal RR. 2009. Synthesis of novel benzo[h]quinolines: Wound healing, antibacterial, DNA binding and in vitro antioxidant activity. European Journal of Medicinal Chemistry 44:981-989.

Nair SN, Nair MS, Nair DV, Juliet S, Ravindran R. 2014 Wound healing, anti inflammatory activity and toxicological studies of leea asiatica (1.) Ridsdale. International Journal of Biological and Pharmaceutical Research 5:745-749.

Ornitz DM, Itoh N. 2015. The fibroblast growth factor signaling pathway. WIREs Dev Biol 4:215-266.

Rashid SAH, Halim AS, Muhammad NA. 2008. The effect of vitamin $\mathrm{E}$ on basic fibroblast growth factor level in human fibroblast cell culture. Med J Malaysia 63:69-70.

Shi HX, Lin C, Lin BB, Wang ZG, Zhang HY. 2013. The Antiscar effects of basic fibroblast growth factor on the wound repair In Vitro and In Vivo. PLoS ONE 8:e59966.

Sogabe Y, Abe M, Yokoyama Y, shikawa O. 2006. Basic fibroblast growth factor stimulates human keratinocyte motility by Rac activation. Wound Repair and Regeneration 14:457-462.

Spaccapelo Luca MD. 2016. Rationale for basic fgf in wound healing and review of therapeutic applications. European Journal of Pharmaceutical and Medical Research 5:51-59.

Srivastava N, Jain GK, Raghubir R. 2011. Poly antioxidant mixture accelerates healing of experimental wounds in albino rats. Asian Journal of Pharmaceutical And Clinical Research 4:46-50.

Suriadi. 2004. Perawatan Luka Edisi I. Jakarta: CV Sagung Seto. Thiele JJ, Mudiyanselage SE. 2007. Vitamin E in human skin: Organ-specific physiology and considerations for its use in dermatology. Molecular Aspects of Medicine 28:646-667.

Triyono, Bambang. 2005. Perbedaan Tampilan Kolagen di sekitar Luka Insisi pada Tikus Wistar yang diberi Infiltrasi Penghilang Nyeri Levobupivakain dan yang tidak diberi Levobupivakain. Semarang: Universitas Diponegoro.

Wild T, Rahbarnia A, Kellner M, Sobotka L, Eberlein T. 2010. Basics in nutrition and wound healing. Nutrition Review 26:862-866. 